\title{
THE REFLEXIVE JOURNAL: \\ INSIDE THE BLACK BOX
}

\author{
John Tribe \\ University of Surrey, UK \\ Honggen Xiao \\ The Hong Kong Polytechnic University, Hong Kong \\ Donna Chambers \\ University of Surrey, UK
}

\begin{abstract}
It was Habermas who commented on the fact that knowledge is never interest free. But it often appears to be on the surface. Journals with their rigorous systems of double blind peer review certainly do their best to avoid partiality and add to the trustworthiness of the process. But their deeply routinised systems contribute to the "black boxing" of knowledge production. This article wishes to examine aspects of interests in knowledge. It does this by three routes of analysis. First it presents data on journal structures and process. Second it finds patterns and trends in knowledge development. Third it critically reflects on the nature of new knowledges produced. In doing so it seeks to make the workings of the black box of Annals more transparent. Keywords: Journal, Reflexivity, Knowledge, Black Box.
\end{abstract}

\section{INTRODUCTION}

Black boxes are running quietly, purposefully and often unobtrusively throughout the world. They are found at road junctions controlling traffic lights, in whole buildings connecting telephones, and of course in the skies recording the minute-by-minute actions of air crew. In the academic realm, Latour (1999) explains 
that blackboxing occurs when the business of science

'is made invisible by its own success. When a machine runs efficiently, when a fact is settled, one need only focus on its inputs and outputs and not its internal complexity'(p.304).

In other words we often fail to observe or be conscious of the internal mechanisms or structures that govern knowledge creation. Rather we generally go about our academic business in unreflexive mode. As part of this routine of inputs and outputs academic authors submit a constant stream of papers to online editorial systems and finished journals appear at regular intervals on our library shelves. Between these inputs and outputs the black boxes connect, order and direct the people and things that constitute and perform journal networks.

Aitchison (2001) was one of the early authors to have scrutinized the inner workings of these black boxes and her analysis of the gender of authors in leisure and tourism journals found that female authors were outnumbered by male authors by a factor of four to one. The black box was revealed to have a significant gender dimension. Later Tribe (2006) offered evidence of omissions in the tourism canon showing that four areas of research are rarely represented in journal outputs. These are values-based research, “other” knowledges, under-empowered groups, and extra-metropolitan research. What these examples suggest is that journals may not be operating in an interest free manner (Tribe, 2008) and that it might therefore be prudent to investigate more carefully both the internal complexities and the outputs of these black boxes and the possible relations between these.

It is these considerations that provide the rationale for this article which aims to do three things. First some basic data generated by the journal is examined. Second a review is undertaken of the knowledge clusters and directions evident in the last two years of Annals' outputs. Third a more critically reflexive analysis of Annals' knowledge is offered. 


\section{PUBLISHING DATA}

The number of articles submitted to Annals has shown a steady increase from 253 in 2008, rising to 261 in 2009 and 325 in 2010 . The total publication time for articles defined as the time from submission to dispatch of the issue from the warehouse averaged 67 weeks in 2010 and has been steadily falling. Like most journals Annals now posts pdfs of articles on the web as soon as they are available. The rejection rate between 2008 and 2010 was 0.82 with most accepted papers originating from The United Kingdom, The United States, and Australia. Downloads of articles on the web are also increasing steadily from 694,544 in 2008 to 810,762 in 2009 and 903,730 in 2010 with The United Kingdom, China and Australia being the top 3 downloading countries. The five top cited articles since 2006 are shown in Table 1.

Table 1. Top Cited Articles

\begin{tabular}{l|l}
\hline Article & Cites \\
\hline Pan \& Fesenmaier (2006): Online information search: Vacation planning & 52 \\
process & \\
Saarinen (2006): Traditions of sustainability in tourism studies & 50 \\
Reisinger \& Steiner (2006): Reconceptualizing object authenticity & 44 \\
Cooper (2006): Knowledge management and tourism & 44 \\
Tribe (2006): The truth about tourism & 37 \\
\hline
\end{tabular}

Bibliometric data from Journal Citation Reports ${ }^{\circledR}$, published by Reuters Thomson indicate a steadily rising impact factor for the journal from 0.864 for 2007 to 1.949 for 2010.The overall satisfaction rating from authors publishing in Annals has risen from $85 \%$ in 2009 to $97 \%$ in 2011 . Editorial decisions are delegated to 88 resource editors. They represent a variety of subjects and geographical locations. Sixty three are male and 25 female $(28 \%)$. Over the last 3 years there has been a programme of renewal of resource editors with 27 males and 19 females (41\%) appointed. 


\section{DEVELOPMENTS IN KNOWLEDGE}

Annals published 124 full length articles in Volumes 37 and 38, covering a variety of subjects from diverse social sciences perspectives. The topics of the main research articles are highlighted and succinctly discussed in six subject categories.

\section{State-of-the-Art Reviews, Theory and Methodology:}

Reflections on knowledge production, theoretical state-of-the-art, and methodologies have constituted a major subject area of published research. In the past two volumes, articles on this subject are characteristic of state-of-the-art reviews and critiques, methodological contributions, paradigmatic discussions, and theory development and applications.

Beginning from 2011, Annals introduced a new feature - an invited review article - to open each issue. These review articles aim at clarifying the state of the art and formulate future research agendas on key issues in tourism studies (Tribe \& Xiao, 2011). In Volume 38, four comprehensive review and critique papers were published. In the first review article, Williams and Shaw (2011) address the themes of innovation and internationalization in tourism research and practice. Anchored within the economics and knowledge literature, the interrelationships between innovation and internationalization are conceptualized and articulated in such a way that the specificities of tourism in a changing global environment can be addressed. In the second issue, Becken (2011) provides a critical meta-analysis to assess current knowledge of tourism and oil; her analysis suggests that activities relevant to tourism and oil are multidimensional and that components of the phenomena are inadequately conceptualized and consequently poorly understood. The third review article relates to technology and intelligent systems in tourism (Gretzel, 2011). Based on a critical review of the widespread use of technology and intelligent systems in information 
search, decision-making as well as work processes in tourism, Gretzel discusses critical gaps in this body of knowledge and calls for a better conceptualization of technology in tourism studies. In the last issue, Richards (2011) reviews the state of the art of creativity and tourism, and critiques on the emergence of creative tourism along with the promotion of creative industries, creative cities and creative class as integration strategies in the commodification of culture and everyday life.

In addition to these invited review articles, a number of other critique papers are notable in the latest volume. Valtonen and Veijola (2011) argue that our understanding of tourist experience could be theoretically and practically incomplete unless the relationship between tourism and sleep (or sleep in tourism) is better understood. Their review proposes interesting avenues for future inquiries into the embodied state and/or agency of overnight visitors staying in (or traveling to) places away from home. On the basis of their review of destination development research, Haugland, Ness, Gronseth and Aarstad (2011) develop a theoretical framework highlighting destination capabilities, coordination and inter-destination collaboration as impact factors of destination development. Weaver (2011) focuses on the potential of military industries or the war economy for pleasure-oriented consumption such as tourism, while Ladkin's (2011) review focuses on the complexities of tourism and labor from the perspectives of workers, employers and researchers. Baggio, Scott and Cooper (2010) present a review and critique on network science in the context of tourism. In their assessment of the theoretical state of the art, Papathanassis and Beckmann (2011) apply observations from tourism studies to the domain of cruise research, noting similar pre-paradigmatic and multidisciplinary features of fragmentation, managerialism, and lack of unifying theoretical perspectives in its knowledge creation.

In terms of methodology and methods used in its published research, Annals has 
maintained its position as a predominantly qualitative journal. Of the 124 full length contributions, 70 articles (56\%) follow qualitative inductive approaches (including case studies); 32 articles (26\%) adopt quantitative deductive methodology; 18 contributions (15\%) are conceptual/review articles; and four papers (about 3\%) use mixed method approaches (Table 2).

Table 2. Methodology of published full-length research (Annals 2010-2011)

\begin{tabular}{l|c|c|c|c}
\hline & $\begin{array}{l}\text { Qualitative (including } \\
\text { case studies) }\end{array}$ & Quantitative & Conceptual/review & Mixed methods \\
\hline 2010 & $33(63 \%)$ & $12(23 \%)$ & $5(10 \%)$ & $2(4 \%)$ \\
2011 & $37(51 \%)$ & $20(28 \%)$ & $13(18 \%)$ & $2(3 \%)$ \\
Sub-total & $70(56 \%)$ & $32(26 \%)$ & $18(15 \%)$ & $4(3 \%)$ \\
\hline
\end{tabular}

Qualitative-inductive approaches in the past two volumes include ethnographies of volunteer tourism (Conran, 2011) and of rural destination development and change in a critical post-colonial context (Tucker, 2010), comparative case studies of migration patterns and tourism development in Spanish island destinations (Dominguez-Mujica, Gonzalez-Perez \& Parreno-Castellano, 2011), critical discourse analysis to examine the construction of freedom in tourism texts produced by cultural brokers (Caruana \& Crane, 2011), and visual autoethnography as a method for exploring tourists' experiences (Scarles, 2010). Deductive approaches are exemplified by the use of scale development to measure leisure constraints (Hung \& Petrick, 2010), international tourism demand modeling and forecasting (Shen, Li \& Song, 2011), as well as experimental design to understand the attitudes of students towards tourists with disabilities (Bizjak, Knezevic, \& Cvetreznik, 2011).

Critical Tourism Studies. From paradigmatic standpoints, main articles published in Annals have displayed a strong orientation towards critical, interpretive scholarship. In this regard, Pritchard, Morgan and Ateljevic's (2011) reflexive account outlines 
values-led humanistic approaches towards "hopeful tourism." In addition, hermeneutic and phenomenological approaches are explored by Ren, Pritchard and Morgan (2010) and Pernecky and Jamal (2010) in the contexts of constructing research and producing knowledge, and by Sedgley, Pritchard and Morgan (2011) in their development of a transformative agenda for tourism and ageing research. In the same line of epistemic reflections and state-of-the-art reviews, Tribe (2010) critically analyzes the nature and structure of tourism studies as well as the formation of culture and networks amongst its academics; Racherla and $\mathrm{Hu}$ (2010) report on research collaborations on the basis of co-authorship patterns visible from tourism journals. Also falling within the paradigmatic discussion is Feighery's (2011) article on the role of tourism scholars as consultants or knowledge brokers in a (the) scientific community and the induced concerns of ethics in professional practices. Actor-Network Theory. The applications of existing theories to, or adaptations of theoretical models in tourism studies have been remarkable. In particular, a number of articles in these two volumes adopt or apply actor-network theory in their interpretations. For example, Ren's (2011) study introduces the notions of non-human agency and radical ontology, and demonstrates how destination realities are constantly negotiated and altered through the linkages of multiple actors, discourses and practices. Povilanskas and Armaitiene (2011) employ the same theory in their critical interpretation of transformation and development of tourismscape in a Baltic seaside resort-hinterland nexus. Likewise, Paget, Dimanche and Mounet (2010) adopt actor-network theory to examine reconfiguration of resources for creativity and innovation in resort business.

Notably, in line with the orientations of critical tourism studies, a number of authors have adopted a critical theory approach to the scrutiny of tourism research and scholarship (Pernecky \& Jamal, 2010; Ren, Pritchard \& Morgan, 2010), and to their 
interpretation of tourism as an encounter for individuals with vision problems (Richards, Pritchard \& Morgan, 2010). From the consumer behavior perspective, a number of studies revisit behavior, tourist decision-making, and destination choice (Decrop, 2010; Krider, Arguello, Campbell \& Mora, 2010; Smallman \& Moore, 2010).

In addition, collaboration and network theories have also been utilized in destination and tourism development contexts. For example, Beritelli's (2011) study focuses on cooperation among prominent actors in an Alpine destination in its planning towards sustainable development. Wong, Mistilis and Dwyer (2011) propose a model in their examination of intergovernmental collaboration in tourism among ASEAN nations. Erkus-Ozturk and Eraydin (2011) research into the factors of global connectivity in Antalya's tourism and explore the importance of global links to companies in tourism clusters in their study region.

\section{Cultural Representation and Image}

Often cross-referenced to topics such as interpretation, semiotics, and language, cultural representation, identity and image have collectively formed an important subject area, with numerous contributions in Annals Volumes 37 and 38, addressing a diverse set of tourism issues from largely cultural studies perspectives.

The use of media for representing cultures and places has attracted increasing attention from tourism academics. To enhance the understanding of tourists' own agency in destination marketing and the creation of tourist spaces, Mansson (2011) applies a new media concept of convergence to examine the instances of tourists themselves creating media products and images which in turn circulate online through various channels like social media. Using tourism advertisements and promotional images, d'Hauteserre (2011) reports a postcolonial discourse analysis which addresses 
the politics of postcolonial representation of New Caledonia as a destination. In a similar context, Patil (2011) contrasts state-produced websites versus corporate websites in his narrative of political history and tourism in the Northeast of India.

With respect to destination image, Pan and Li's (2011) study focuses on the keywords tourists use for their online information search; using China as an example, the authors find that destination image of a country is dominated by a few very popular phrases. Drawing from two state-sponsored tourism campaigns, Frohlick and Johnston's (2011) study on Costa Rica and New Zealand illustrates how places and bodies are co-constructed and heterosexualized through the employment of landscape tropes of nature, pureness, wilderness and escape. Holman's (2011) textual analysis of an ayahuasca website explores the complex social and cultural phenomenon of spiritual tourism to the Amazon and how the commodification of culture has changed the locals' and tourists' image of the place.

In addition to web-based texts, fictional stories, movies, literary texts and 'holiday talks" constitute unique forms for representational studies. Using conversation analysis of travel story retellings and reminiscence, McCabe and Stokoe (2010) examine the social actions accomplished in (or by) such holiday talks. Osagie and Buzinde (2011) explore postcolonial literary texts that engage the realities of tourism; their criticism of an earlier autobiographical text suggests that the meanings of colonial heritage can change over time, along which hosts and guests tend to value the same things in the shared space of the contact zone. Using the novel of Dracula as a text, Reijnders (2011) investigates why people feel the need to connect fictional stories with physical locations, and explains how Dracula tourists are driven by the desire to compare (confirm or disconfirm) their mental image with the landscapes they visit. Moreover, Frost's (2010) analysis provides an interesting discussion on how fictional-feature movies project the image and attributes of a destination and will 
likely have profound life-changing experiences for potential tourists.

Framed within the politics and theory of postcolonial representation, a number of articles address tourists' reactions to, and their co-construction of, landscape transformation and biophysical and climate changes in coastal destinations (Buzinde, Manuel-Navarrete, Kerstetter \& Redclift, 2010; Buzinde, Manuel-Navarrete, Yoo \& Morais, 2010). Juxtaposing cultural representation and national identity of Korea, Park's $(2010,2011)$ studies look at heritage tourism as an emotional journey into national memory and nationhood. The author explores the views of heritage as cultural production and its fundamental role in maintaining national solidarity; she further suggests that shared national memory is of crucial significance in encouraging South Korean nationals to reaffirm their ethnic and cultural affinities with North Korea. In a similar vein, Yang (2011) examines the representation of minority culture in China's Southwest Yunnan Province, and reports on cultural hegemony in ethnic tourism development.

In addition, the use of culture or heritage and the consequences associated with such exploitations constitute another perspective on tourism and cultural studies. Using Maori culture as an example, Amoamo (2011) examines hybridity and the renegotiation of cultural identities in indigenous tourism. Eriksson's (2010) historical account draws from the notions of dirt and cleanliness to examine tourist constructions of differences between themselves and other people, and to conceptualize modernity. The author argues that tourist perceptions of cleanliness and dirt can be used to mediate modernity, race, and the authenticity of cultural experiences. Furthermore, Watkins and Gnoth (2011) introduce a value orientation approach to understanding culture in tourism studies.

\section{Tourist Experience}


Researchers in the last two volumes have employed a variety of social sciences perspectives to look at issues pertaining to tourist experience, authenticity, and typologies of tourists. Specifically, topics on alternative tourist experience encompass backpacking as a way of life (Cohen, 2011; Enoch \& Grossman, 2010; Larsen, Ogaard \& Brun, 2011), ecotourism, rural or nature-based tourism (Rantala, 2010; Rickly-Boyd \& Metro-Roland, 2010), adventure travel and outdoor recreation (Buckley, 2010), pilgrimage or religious tourism (Collins-Kreiner, 2010), and beach tourism (Andriotis, 2010; Baldacchino, 2010).

Drawing upon critical social theory on embodiment, Waitt and Duffy's (2010) study of musical festivals reflects upon conceptual and methodological implications for researching tourist-oriented festivals and performances when the delivery of experience turns from the visual to the aural aspects of the tourist body. Maoz and Bekerman's (2010) discussion challenges the traditional etic approach in favor of an emic perspective for the scrutiny of postmodern tourist experience. Drawing from cognitive processes and memory formation and retention from the field of psychology, Tung and Ritchie (2011) explore the essence of memorable tourism experience and reveal its four key dimensions of affect, expectations, consequentiality, and recollection. Based on research into tourists' experience of the English Lake District, Sharpley and Jepson's (2011) study examines the relationship between rural tourism and spiritual experiences, revealing that although tourists do not purposefully seek spiritual fulfillment, their visits frequently embrace a subconscious emotional dimension. Moreover, based on evidence from Las Vegas (Nevada, USA) and Gold Coast (Queensland, Australia), Weaver's (2011) exploratory study focuses on contemporary tourism heritage and categorizes their presentational characteristics. Another type of tourist experience often documented by Annals' researchers relates to thanatourism or dark tourism. Biran, Poria and Oren's (2011) interpretation 
sheds light on the nature of dark tourism experience by clarifying the relations between the symbolic meanings assigned to their study site and the core elements of tourist experience. Causevic and Lynch's (2011) study locates post-conflict tourism in Bosnia and Herzegovina in the context of social renewal of the destination and its people. Based on a study in the Holocaust museum in Jerusalem, Cohen's (2011) inquiry indicates that authentic sites at the location of a tragedy are important aspects of a meaningful encounter through dark tourism. In addition, Mowatt and Chancellor's (2011) undertaking on dark tourism relates to sites associated with enslavement and trans-Atlantic slavery in Ghana.

Authenticity has remained a hot topic of interest for both empirical and conceptual discussions in Annals. Andriotis (2011) examines heritage authenticity in the context of a religious heritage or pilgrimage landscape in Greece; his study links Pine and Gilmore's (2007) five genres of authenticity (i.e., natural, original, exceptional, referential, and influential) with prior research on pilgrimage experience. Buchmann, Moore and Fisher (2010) report on a case study of film-induced tourism to New Zealand and discuss on object authenticity, existential authenticity, sincerity of relationships, and embodied experiences of place. Departing from a social realist perspective, Lau's (2010) revisit of authenticity argues for the notion to be conceptualized solely as object authenticity and de-linked from other concepts such as existential authenticity. Drawing from observations of community-based tourist performances in Papua New Guinea, Martin (2010) discusses the importance of competing claims of authenticity to the understanding of social contexts and divisions within which tourism is practiced.

Relating to authenticity and tourist experiences are contributions pertinent to the roles or typologies of tourists. Stylianou-Lambert's (2011) study on visitors to art museums reconstructs and expands cultural tourist typologies through the 
identification of different ways of perceiving art museums. Hyde and Olsen (2011) employ grounded theory methods to examine tourist packing practices as planning and preparation for touristic performances; their analysis presents a substantive theory of travel bags through the lens of Giddens' grand theory of self-identity. Focusing on mythic journeys of modern tourists visiting remote and exotic frontier destinations, Laing and Crouch's (2011) research adds to discussions on metempsychotic tourists and their travel motivations and experiences. In addition, Tsaur, Yen and Chen (2010) explore the conceptualization of independent tourists' knowledge and skills through developing their knowledge constructs such as onsite travel capability, pre-trip preparation, and emergency response.

\section{Planning and Development in Destinations and Attractions}

A number of articles in the last two volumes address topics pertaining to policy, planning and development. Central to this subject area is research on tourism policy at different destinations. For example, Farsari, Butler and Szivas (2011) use complex systems and cognitive mapping approaches in their study of sustainable tourism development in Greece. Airey and Chong (2010) report on a study of the key players and institutional processes involved in national tourism policy-making in China. Lee, Riley and Hampton (2010) analyze the dynamics of political involvement that influences progress of heritage sites in Korea. Instances of policy implementation, dependency and development in different parts of Thailand are examined by Krutwaysho and Bramwell (2010) and Lacher and Nepal (2010) respectively. Furthermore, Nyaupane and Timothy (2010) report on the political aspects of tourism policy in Bhutan.

In addition, residents' attitudes towards tourism constitute another area of interest within the domain of planning and development. Notably, these articles 
largely adopt scientific approaches to developing models or testing hypotheses with regard to community support of tourism. For example, while Nunkoo and Ramkissoon (2011), using structural equation modeling, develop a model of community support of tourism on the basis of social exchange theory, Ward and Berno's (2011) research goes beyond social exchange theory to test a predictive model of attitudes towards tourists. After an extensive critique of existing research, Vargas-Sanchez, Porras-Bueno, and Plaza-Mejia (2011) construct an enhanced explanatory model and test it in an emerging destination in Spain. Moreover, Amuquandoh (2010) examines residents' subjective definitions of tourism and its perceived impacts on development in Ghana; Kask, Kline and Lamoureux's (2011) conceptual discussion models the choices from the demand and supply sides to enhance community-based development for the scientific, academic, volunteer and educational tourist market.

Also falling within this subject domain are articles on sustainability or sustainable development in a destination or attraction (Miller, Rathouse, Scarles, Holmes \& Tribe, 2010; Nyaupane \& Poudel, 2011; Strickland-Munro, Allison \& Moore, 2010), research into the role of tourism in rural development and poverty alleviation from community development perspectives (Deller, 2010; Matarrita-Cascante, 2010), as well as studies on "contrived" wildlife attractions in postmodern societies (Knight, 2010). In addition, Weidenfeld, Williams and Butler's (2010) study demonstrates that spatial proximity, product similarity and market similarity generally facilitate knowledge transfers and innovation spillovers at local and regional scales in the attraction sector.

A variety of other development aspects of attractions/destinations have also received attention from researchers. Frantal and Kunc (2011) assess and empirically verify the effects from the construction of wind turbines on landscape image and 
tourism potential of a destination. Garay and Canoves' (2011) study combines tourism area life cycle with regulation theory in their analysis of long-term historical development in a Spanish destination. Furthermore, Lorenzini, Calzati and Giudici (2011) adopt statistical analysis in their attempt to understand the impacts of territorial brands on tourism development in Italy, while Gelbman and Timothy (2011) examine the development of tourism in border communities or international exclaves.

\section{Motivation, Behavior and Decision}

Motivation, behavior and decision have also been a prominent subject of research in the last two volumes of Annals. With empirical evidence of tourist time-space activities in Hong Kong, Shoval, Mckercher, Ng and Birenboim's (2011) research reports a profound impact of hotel location on tourists' movements, activities and behavior in an urban destination. Alegre and Garau's (2010) study suggests that a tourist's experience of satisfaction or dissatisfaction needs to be defined within a specific context of evaluation. Dwelling upon frequent short-haul air travel as behavioral addiction, Cohen, Higham and Cavaliere's (2011) research looks into the tension between tourism consumption and changing social norms towards acceptable flying practice.

Moreover, the phenomenon of deviant behavior is researched by Uriely, Ram and Malach-Pines (2011) from the perspective of psychoanalytic sociology. Drawing on notions and theories of Sigmund Freud and Carl Jung, these authors argue that various unconscious drives can either be gratified by normative tourist activities that involve adaptive defense mechanisms or lead to deviant tourist behavior that entail distorting defense mechanisms. Similarly, Goulding and Shankar (2011) examine club culture and propose the concept of ritual as an explanatory framework for understanding clubbing behavior as a co-created experience. 
Wong and McKercher (2011) report on the findings of a qualitative study of tourists seeking destination information and staff at tourist information centers in Macau, and develop a model of information brokering to account for such exchanges and processes. Denstadli, Jacobsen and Lohmann (2011) examine vacationers' perceptions of weather conditions in Northern Scandinavia, with observations adding to discussions on tourists' weather expectations, perceptions and adaptive vacation behavior. Wang, Jao, Chan and Chung (2010) explore intrinsic risks and risk perceptions of Taiwanese tour leaders and conclude with managerial implications of understanding risk perceptions for package tour operations.

In addition, with empirical evidence from Ghana, Boakye's (2010) study of tourists as targets of crimes finds that modes and options of travel significantly relate to the degree to which tourists are exposed to crimes. Chang, Kivela and Mak's (2010) inductive study of Chinese tourists' food preferences comes up with a typology to describe and contrast the participants' dining attitudes, motivations and behavior while traveling in overseas destinations. Moreover, with university students as study participants, Gurel, Altinay and Daniele (2010) investigate the relationship between entrepreneurial traits, socio-cultural background and entrepreneurial intention from the perspectives of education, training and professional development.

\section{Economic and Business Aspects}

Annals is a social sciences journal largely characterized by qualitative inquiries. Nevertheless, the managerial and applied nature of tourism has attracted the attention of researchers contributing to this journal. Notably, in the last two volumes, a number of articles address economic and business aspects of tourism. For example, Barros and Machado's (2010) economic study treats tourist length of stay as a determinant rather than a constraint on destination demand. Frechtling's (2010) review focuses on 
concepts, definitions and structure, and macroeconomic variables used in tourism satellite accounts. Song, Kim and Yang (2010) introduce bias-corrected bootstrap as a new statistical method to address elasticity of tourism demand for Hong Kong. Following similar economic perspectives, Seetanah's (2011) study assesses the dynamic economic impacts of tourism for island economies; Nicolau (2011) analyzes both monetary and non-monetary costs of tourists staying at destinations to engage in leisure activities. Moreover, Pratt's (2011) research uses a variety of tools to evaluate the economic importance of tourism to Hawaii as it moves from an agricultural to a service-oriented economy. His study indicates that the size of tourism's economic contribution is dependent on the import propensities of tourists' spending and the tourism-oriented sectors as well as their backward and forward linkages.

In the domain of business, Zhao, Ritchie and Echtner's (2011) study applies the concept of social capital to help generate an understanding of tourism business development in China. Nam, Ekinci and Whyatt (2011) investigate the mediating effects of consumer satisfaction on the relationship between brand equity and brand loyalty in the hotel and restaurant business. Through assessing cultural differences, Rittichainuwat (2011) examines tourist barriers to visiting disaster-/tsunami-hit destinations with implications for business recovery. Drawing from a study on the experiences of Polish migrant workers employed in the UK tourism sector, Janta, Brown, Lugosi and Ladkin (2011) report on how tourism employment and work place experiences influence migrant workers' adaptation in the host society. In addition, Bosworth and Farrell (2011) explore the role of in-migrant owners of small tourism businesses in promoting entrepreneurship and developing competition in the tourism economy of Northumberland in the United Kingdom.

In sum, Annals Volumes 37-38 mark an important mileage in its contribution to tourism knowledge and scholarship. As noted by Tribe and Xiao (2011), tourism 
studies has been evolving to increasingly reflect inter-and post-disciplinary features with interrelated-ness of its published subjects and collaborations of research endeavors. It is our belief that theories indigenous to tourism are likely to be developed or enhanced through studies incorporating and departing from diverse social sciences problems and perspectives.

\section{CRITICAL REFLEXIVITY}

The purpose of this section is to critically reflect on the nature of new knowledges produced, their methodologies and methods of production and the agents or voices which have been dominant in this production. In this context we also concomitantly reflect very briefly on those knowledges and voices which have been either under-represented or silenced. It is against this background that the critical reflections which follow are subdivided into four overarching sections - Reflections on Methodologies; Reflections on Methods; Reflections on Agents of Knowledge Production; Reflections on Paradigms and the nature of knowledge. The sections that follow do not seek comprehensiveness in terms of the articles to be reflected upon, but seek instead to highlight the main themes that are of relevance, selecting only those articles that are illustrative of these themes.

\section{Reflections on Methodologies}

According to The American Heritage Dictionary of the English Language (2000), the term 'methodology' properly refers to the 'theoretical analysis of the methods appropriate to a field of study.' Silverman (1993, p.2), in a very brief description of the term, notes that 'methodology' can be used to refer to the 'general approach to 
studying a research topic.' Within the tourism literature Jamal and Hollinshead (2001, p.70) explain cogently that a methodology is essentially the "theory of the method, including its epistemological and ontological assumptions.' In this sense, epistemology refers to the 'philosophical inquiry into the nature of knowledge, what justifies a belief' (Alcoff, 1998, p.viii) or in other words, what is meant by a truth claim. On the other hand, ontology refers to the study of the nature of being itself, that is, it raises issues about reality and what exists. So it can be argued that questions of methodology would address both a theory of knowledge (epistemology) and a theory of being (ontology). Simply put, a methodology should establish from the outset one's philosophical approach to the study of a particular research problem regardless of one's disciplinary approach.

Conversely, a method is concerned, not with matters of epistemology, ontology or theory, but with pragmatic issues concerning the particular practices and techniques which are applied in the process of research. Schwandt (1994, p.119) notes that the term method refers to the 'techniques for gathering and analyzing data.' In the social sciences methods might broadly include quantitative techniques (e.g. survey research, economic modelling, etc.) and qualitative techniques (e.g. participant observation, focus groups, etc.) which are, arguably, underpinned by positivist and interpretative methodologies respectively. Importantly, the method selected to conduct research should be guided by, and grounded within, a particular methodology. Put another way, the particular methodology subscribed to by a researcher will determine the method used to undertake the research. Both methodology and method, while they refer to different phenomena, are important and complementary aspects of any research undertaking.

However, again according to The American Heritage Dictionary of the English Language (2000), 'In recent years, methodology has been increasingly used as a 
pretentious substitute for method in [social] scientific and technical contexts...(and) this misuse of methodology obscures an important conceptual distinction between the tools of scientific investigation (properly methods) and the principles that determine how such tools are deployed and interpreted.' An emphasis on method and a concomitant relegation of methodology often serves to obfuscate the nature of the problem under enquiry. In this regard, Schwandt (1994, p.119) observes that 'a focus on methods...often masks a full understanding of the relationship between method and inquiry purpose.'

Our review of the articles in the two volumes of Annals which are the subject of this editorial, reveal that many of the discussions which were included under a subheading of methodology, were merely statements of method and there are many instances where only a section titled 'study methods' was included with no concomitant discussion of methodology. A keyword search of both volumes revealed that the word epistemology only appeared in 19 publications or $15 \%$ of the total 124 papers. Similarly the word ontology only appeared in 20 publications or $16 \%$ of the total 124 papers. However, deeper probing of these papers revealed that there was overlap as many of the papers which include mentions of epistemology also include mentions of ontology. Further, in some of the articles, these words appeared only in the titles of citations in the list of references but were not mentioned or explored in the articles themselves.

So that it would not be unreasonable to assert that there has been a dearth of engagement with methodological discussions of epistemology and ontology in the volumes under review. Indeed where these discussions do exist they seem to be focused almost exclusively in those papers which take a more qualitative approach to research suggesting that papers which adopt a more quantitative approach do not engage with questions of methodology. That said, even within what are ostensibly 
qualitative papers there is little or no mention or discussion of methodological issues. Pritchard et al (2011) note cogently that 'tourism enquiry has remained on the margins of many of the philosophical debates which have energized the social sciences' ( $p$. 947). The following paragraphs briefly outline how issues of methodology are mentioned in some of the papers appearing in both Volumes 37 and 38.

In terms of ontological discussions, Smallman and Moore (2010) suggest that 'studies of tourist decision making seldom address ontological orientation' (p. 398). Cohen et al's (2011) study on binge flying subscribes to a relativist ontology, while Causevic and Lynch (2011) whose article is underpinned by a critical theoretical approach indicate that ontology is 'an anathema of critical theory' (p. 789). Pernecky and Jamal (2010) indicate that hermeneutic phenomenology is located within the context of realist ontology and an epistemology based on interpretation, co-construction and reflexive participation. Similarly, Pritchard et al (2010) outline the ontology of hopeful tourism as 'participative reality [which] is shaped by social, political, cultural, economic, ethnic and gender values and underpinned by power structures (p.951). Ren et al (2010) mention ontology in their discussion of Actor Network Theory (ANT) which they indicate has a 'relational ontology and methodology' that highlights 'associations and multiplicity rather than division' (p.889) and 'rejects the existence of a constant and homogenous body of knowledge' (p.890). Ren (2011) continues this discussion of ANT by speaking of its 'radical ontology' which 'performs tourism objects and realities in multiple ways' (p. 860). Povilanskas and Armaitiene (2011) also draw on ANT which they suggest has three "coherent cognitive notions or "strands of preoccupations" (p.1158) which are simultaneous. One of these strands is an ontological claim of the "networked ordering of actors' which indicates that ANT can be considered "the semiotics of materiality" (p. 1158). 
Scarles (2010) on visual autoethnography suggests that it is 'in combining researcher and respondent ontologies through active exchange within space of the interview that the poesis of visual anthropology arises' (p. 910). Rantala (2010) uses the concept of affordances which she explains subverts the subject-object dualism since affordances 'exist both objectively and in relation to the perceiver' (p.258). In this light, she continues, the 'immediate interaction between the environment and the perceiver is central in the ontology and epistemology of the concept of affordance' (p.260). In addition Becken (2011) discusses the ontology of critical realism which she sees as apt for the study of tourism and oil.

With regard to discussions of epistemology, Tribe and Xiao (2011) suggest that the 'epistemology of tourism is under ever more radical scrutiny and critique' (p.23) and certainly Baggio et al (2010) on network science defend the 'epistemological legitimacy of applying the laws and methods of physics to a social activity such as tourism' (p.811), while Waitt and Duffy (2010) purport to outline what they deem as an 'epistemology of listening' in the context of tourism studies. Causevic and Lynch (2011) suggest that critical theory is 'defined by its epistemology' which is 'knowledge-creation seeking political emancipation of historically silent voices' ( $p$. 789). For his part, Tribe (2010) investigates the epistemological nature of the tourism field which he refers to as an 'academic territory.'

With regard to the issue of reflexivity, Charmaz and Mitchell (1997, p.193) note that

Scholarly writers have long been admonished to work silently on the sidelines, to keep their voices out of the reports they produce, to emulate Victorian children: be seen (in the credits) but not heard (in the text). 
Reflexivity means that the analyst must be sensitive to the 'ways in which the researcher's presence in the research setting has contributed to the data collected and [how] their own a priori assumptions have shaped the data analysis' (Murphy et al, 1998, p.188). It is axiomatic that researchers are active participants in the research process and as such reflexivity points to the need to understand the researcher's location of self (e.g. in terms of class, race, gender, ethnicity, citizenship, ideology, etc.) (Hertz, 1997). Henwood and Pidgeon (1993) indicate that reflexivity implies that the researcher and the researched are interdependent in the social process of research. The use of the first person is an indication of reflexivity in academic writing and in Volume 38, Tribe and Xiao (2011), state that the prohibition on the use of the first person has 'now been lifted with the following proviso - the first person is allowable if the method deployed by the research justifies and explains its use' (p.9). Consequently, there have been several uses of the first person in Volumes 37 and 38 but in some instances there is no apparent justification or explanation for its use. Indeed in many of the papers which use the first person (singular or plural) it seems to represent a writing style rather than a particular epistemological positioning of self within the text. To use a theatrical metaphor, the author(s) often make an appearance in the text, but as 'extras' rather than as protagonists.

There are however some exceptions. For example, Tucker (2010) notes that she is 'grateful that Annals of Tourism Research is now accepting the 'I' of the researcher because this allows me to ...make explicit my own entanglement in my research field' (p. 931). Through conducting long term ethnographic research between 1995 to 2009, Tucker thus refers to her role in the 'worldmaking function of tourism studies' as 'tourist-cum-researcher' (p.931). Andriotis (2010) in his study of heterotopic erotic oases locates himself in the research as a 'heterosexual man in a predominantly gay beach' and as a 'non-participatory insider' (p. 1083). He also discusses the ethical 
considerations inherent in engaging in covert observation which did not involve 'sexual participation' (p. 1083) and how this might have affected his interpretation of the research findings. Anne- Marie d'Hautessere (2011) in her discussion of the politics inherent in the imaging of New Caledonia reflects on her position as an outsider to the society which she is studying and indicates that she therefore cannot be presumed to speak for her informants. Frohlick and Johnston (2011) discuss their respective personal backgrounds and theoretical and methodological location within their research on tourism media campaigns and heterosexualities in Costa Rica and New Zealand.

Importantly, Amoamo (2011) locates herself as a Maori researcher who draws on a 'Kaupapa Maori perspective [which is] an epistemological framework that recognises and reasserts Maori values and identity' (p.9). She also indicates that she is both an insider and an outsider thus emphasising the heterogeneity of Maori identities. It is interesting that Tribe (2010) in his critical analysis of the epistemological status of tourism studies with a focus on the culture and practices of academics does not use the first person ' $\mathrm{I}$ ' in his discussion but nevertheless locates himself in the research as 'positioned' and 'embodied' (p.9). He considers that while he strived to 'cultivate an open mind' he was nevertheless 'reflexively aware of the limits to this' (p.9). Similarly Conran (2011) explains her multiple positionalities and subjectivities within the research but does not use first person narrative.

\section{Reflections on Methods}

We noted that Annals has maintained its position as a predominantly qualitative journal. However, in this section we seek to unpack the multiplicity of methods of data collection and data analysis used in both quantitative and qualitative approaches in order to determine the extent to which creative or innovative techniques have been 
employed. We found that most of the qualitative studies used traditional methods for the collection of data, predominantly interviews (Buzinde et al, 2010; Causevic \& Lynch, 2011; Lee et al, 2010; Stylianou-Lambert, 2011); focus groups (Cohen, 2011; Sharpley \& Jepson, 2011) and participant observation (Buckley, 2010; Reijnders, 2011). Some of these methods were carried out in the context of ethnographic studies (Maoz \& Bekerman, 2010; Park, 2011; Tucker, 2010). Data was also collected from secondary sources (whether available in printed or electronic form - although there is a notable apparent increase in the use of the latter see for example Holman, 2011; Pan et al, 2011; and the use of the concept of netnography - see for example Hyde and Olesen, 2011; Janta et al, 2011).

In terms of qualitative data analysis, traditional methods were evident such as narrative analysis, critical discourse analysis, thematic content analysis (Patil, 2011; Wong \& McKercher, 2011) and analysis using grounded theory (Decrop, 2010; Goulding \& Shankar, 2011; Laing \& Crouch, 2011). Quantitative techniques also demonstrated heavy reliance on surveys and questionnaires (Alegre et al, 2010; Amuquandoh, 2010; Nam et al, 2011; Wang et al, 2010; Zhao et al, 2011). Quantitative data analysis using forecasting techniques and econometric modelling (Seetanah, 2011; Shen et al, 2011), factor analysis, regression analysis; structural equation modelling (Beritelli, 2011; Biran et al, 2011; Lorenzini et al, 2011; Nicolau, 2011; Nunkoo \& Ramkissoon, 2011; Rittichainuwat, 2011; Vargas-Sanchez et al, 2011) predominated.

There were however a few methods used, some of which, while they have been present in the wider social science academy for many years, are nevertheless creatively applied to understand tourism phenomena. These include methods such as the visual techniques of video which Buckley (2010) utilized in his study of health and safety in adventure products; Scarles' (2010) use of visual autoethnography as a 'potential route 
to accessing the embodied, sensual and emotional experiences of tourists' encounters with place' (p. 906); Frost's (2010) analysis of films to investigate the motivational drivers of film-induced tourism in the Australian outback; Miller et al's (2010) study of public understanding of sustainable tourism which used visual stimuli as 'referents.' Similarly, Mowatt and Chancellor's (2011) study of dark tourism and slave castles included photo elicitation techniques. Waitt and Duffy (2010) in their discussion of listening and its relevance to tourism studies provided participants with an audio-recording device to record a 'sound diary'.

Other creative techniques included the use of on line diaries or blogs (Enoch \& Grossman, 2010); the use of 'self ethnography by Ren et al, (2010); McCabe and Stokoe (2010) who analysed 'naturally occurring talk' from audio-recorded conversations in a 'variety of ordinary and institutional settings'; Stylianou-Lambert (2011 included, amongst other techniques, 'personal meaning mapping' and Bizjak et al (2011) who used an experimental method to explore whether a short education programme could positively change students' attitudes towards people with disabilities in general and in the tourism industry specifically. Finally Shoval et al (2011) used GPS loggers to examine the relationship between hotel location and tourist activity in cities. What was interesting in these two volumes was that not only were more creative techniques being used to collect data, but that many researchers were using a variety of different techniques in a single study. Indeed triangulation of techniques was a noticeable feature.

\section{Reflections on Agents of Knowledge Production}

Whilst Tribe (2010) used ANT to explain how non-humans (such as books and journals) have shaped tourism studies most of our discussions in this section focus on human agents and communities of knowledge. 
Human agents: There were a total of 225 different authors from the 124 papers published in both Volumes 37 and 38. The number of authors is higher than the number of papers as many papers were published collaboratively by two or more authors. The geographical location of authors is important as it might provide some indication of underlying power dimensions. Indeed Tribe (2006) suggests that 'when squeezed with a critical grip, the seemingly innocuous concept of geographical location yields up its underlying power dimension' (p.370). In the case of the two mentioned volumes, the geographical location of authors (by university cited at the time of publication) is listed in Table 3:

Table 3. Geographical location of authors

\begin{tabular}{|c|c|c|c|c|c|c|c|c|}
\hline Year & $\begin{array}{l}\text { North } \\
\text { America } \\
\text { (USA } \\
\text { and } \\
\text { Canada) }\end{array}$ & Europe & $\begin{array}{l}\text { Australia/ } \\
\text { New Zealand }\end{array}$ & $\begin{array}{l}\text { Hong Kong, } \\
\text { Mainland } \\
\text { China, } \\
\text { Macau, } \\
\text { Taiwan }\end{array}$ & $\begin{array}{l}\text { Other } \\
\text { Asia/ } \\
\text { Pacific }\end{array}$ & Africa & Israel & Total \\
\hline 2010 & 23 & 38 & 19 & 14 & 1 & 2 & 5 & 102 \\
\hline 2011 & 19 & 63 & 20 & 6 & 5 & 1 & 9 & 123 \\
\hline Total & 42 & 101 & 39 & 20 & 6 & 3 & 14 & 225 \\
\hline
\end{tabular}

It is evident from Table 3 that most of the authors who published in Annals over the two year period emerged from the developed countries in North America, Europe, Australia, New Zealand and Israel. Indeed the total number of authors from these developed societies in this two year period is 196 or $87 \%$ of the total. There is also a fairly significant minority of authors from mainland China, Hong Kong, Taiwan and Macau combined. The African continent continues to be severely under-represented with only three authors and there are no authors of papers from regions in Latin America, the Caribbean or South America. The 'other' Asia/Pacific includes no 
papers from India. What this indicates is that there is still a concentration of research and scholarship in tourism in the developed world which leads to a continued perpetuation of 'Eurocentric' knowledges. Voices from the developing countries, particularly those in the Southern hemisphere many of which are not English speaking, are conspicuous by their absence.

That said, we are cognisant of the fact that this information on the geographical location of authors is not without its limitations. For example, this information is based on the universities where the authors are based and this does not necessarily imply that these authors are all originally from developed countries. Indeed, many developing world scholars have migrated to developed countries for a number of reasons including university education and employment. The question that arises from this then is the extent to which the topics researched and the philosophical approaches adopted nevertheless reflect the realities and positionalities of these authors as peoples from traditionally marginalised societies? To what extent have these scholars managed to resist the adoption of Eurocentric ways of thinking, knowing and being? Or to what extent is there evidence of emergent hybridities? As indicated in our earlier discussion, there is a dearth of papers in these two volumes which include reflexivity with regard to the situatedness of the authors and this information might have provided some clarity in this context.

Another issue here is the breakdown of authors by gender, ethnicity and by seniority. Tribe (2006) speaks to the power of gender in the knowledge force field and it would therefore have been useful to ascertain the gender composition of all the authors. It would have been useful also to ascertain whether there are any correlations between gender and number of articles published, gender and the topics of investigation and philosophical perspectives. In terms of seniority it would be 
interesting to ascertain whether most of the articles in these two volumes have been published by senior academics or whether there have been voices emerging from newer scholars especially doctoral students. Similarly, in terms of ethnicity it would have been useful to discern the relevance of ethnicity in tourism knowledge production. Some of this information such as gender and seniority could be ascertained from the reading of the brief author biographies but in some instances the information provided here was patchy.

Knowledge communities: Our discussion here will turn to the extent to which there are knowledge communities as evident in research collaborations. Racherla and Hall (2010) indicate that collaboration is integral to the growth of academic disciplines especially against the background of the increasing complexity of the problems which face the world today, the dynamism of knowledge growth and the high specialisation evident in areas of expertise. Indeed, collaborations result not only in the sharing of ideas and the development of new knowledges and practices within and across academic fields and disciplines but also fosters social relationships which are essential for the growth of communities of scholars. Racherla and Hall (2010) utilised a social network perspective to analyse tourism research collaborations as evidenced by the co-authorship patterns in three leading tourism journals (Annals of Tourism Research, Tourism Management and Journal of Travel Research) over the ten year period 1996-2005. They suggest that co-authorship 'provides an opportunity to identify and measure the extent of social activity and influence in scientific specialities' (p.1015). Following Racherla and Hall (2010), we similarly sought to ascertain the extent of collaborations based on co-authorships in both Volumes 37 and 38. While we conducted a more rudimentary analysis than that done by Racherla and Hall in their article, Table 4 does provide an indication of the extent to which the 
papers published in these two volumes result from collaborative efforts. It also provides some indication of the extent to which the collaborations that take place are within the same universities, different universities within the same country or whether the collaborations are cross-border collaborations.

\section{Table 4 - Research Collaborations}

\begin{tabular}{llllll}
\hline & $\begin{array}{l}\text { Single } \\
\text { authored }\end{array}$ & $\begin{array}{l}\text { Collaboration } \\
\text { (same } \\
\text { university) }\end{array}$ & $\begin{array}{l}\text { Collaboration } \\
\text { (different } \\
\text { universities, } \\
\text { same country) }\end{array}$ & $\begin{array}{l}\text { Collaboration } \\
\text { (cross-border) }\end{array}$ & $\begin{array}{l}\text { Total } \\
\text { Papers }\end{array}$ \\
\hline 2010 & 20 & 7 & 11 & 14 & 52 \\
2011 & 26 & 17 & 12 & 17 & 72 \\
Total & 46 & 24 & 23 & 31 & 124 \\
\hline
\end{tabular}

It can be seen that of the total of 124 papers, 46 were single authored and 78 were collaborative efforts, or 37 per cent and 63 per cent respectively. Cross border collaborations represented the highest number of collaborations over the two year period although the highest increase in collaborations was by authors who were based at the same universities. These collaborations provide some indication of the extent to which knowledge is being developed and exchanged amongst researchers in tourism and whether we can speak of knowledge communities. Importantly, based on the extent to which the authors of papers in these two volumes are concentrated in the developed world (refer to Table 3), it is evident that the bulk of the cross border collaborations are necessarily concentrated between and amongst authors based in the developed world and also between authors in the developed world and the emergent economies in Asia (notably mainland China, Hong Kong, Macau and Taiwan). 
There is very limited collaboration taking place between developing and developing world with the exception of two collaborations of the 31 identified - one between an author in the United Kingdom and another in Thailand (Krutwaysho \& Bramwell, 2010) and the other between an author in Fiji and another in New Zealand (Ward \& Berno, 2011). It is interesting to note that the three papers from the African region were all single authored. There are two issues here - not only is there an under-representation of developing countries in terms of the location of authors of Annals papers in the two volumes considered here, but there is also a notable lack of collaboration between developed and developing countries. This has implications for the nature of the knowledges produced and, arguably, continues to perpetuate the power imbalances between the developed and developing world.

\section{Reflections on Paradigms and the nature of knowledge}

As indicated earlier in this paper, many of the articles published in Volumes 37 and 38 have embraced critical scholarship and are part of what has been deemed the 'critical turn' in tourism studies. Indeed this is the key paradigmatic shift that seems to dominate the articles in these two volumes. Pritchard et al (2011) in their article on hopeful tourism scholarship, which encapsulates the nature of this 'critical turn', cogently discuss its key philosophical underpinnings. It is evident that this critical turn is largely interpretative and is informed by a range of theoretical perspectives including feminism, humanism, cultural theory and geography. With regard to the latter discipline, the concepts of performance and mobility have been key influences. Indeed, the concept of performance has witnessed its own 'performance turn' in tourism studies which emerged in opposition to the 
occularcentrism of Urry's (1990) concept of the tourist gaze. The performance turn argued instead that the tourist experience is multisensuous, corporeal and embodied. According to Haldrup and Larsen (2010) 'tourists encounter cities and landscapes through corporeal proximity as well as distanced contemplation' (p.3) The performance turn also destabilised the traditionally representational world in which 'places and objects are seen as signifying social constructs that can be unveiled through authoritative cultural readings rather than how they are used and lived with in practice' (Haldrup \& Larsen, 2010, p. 3).

The performance turn thus dislocated 'attention from symbolic meanings and discourses to embodied, collaborative and technologized doings and enactments (Haldrup \& Larsen, 2010, p. 3. emphasis in original). It is in this sense that the performance turn is 'more-than-representational' (Lorimer, 2005). Finally, the performance turn problematizes the understanding of tourism as being about extraordinary and non-routine experiences by turning attention to the quotidian or everyday aspects of tourist performances (Haldrup \& Larsen, 2010). In a related sense there has been also a 'mobilities turn' which has recognised that in tourism there are many different kinds of mobilities. According to Sheller and Urry (2004), mobilities 'shape the places where tourism is performed, and drive the making and unmaking of tourist destinations...tourism mobilities involve complex combinations of movement and stillness, realities and fantasies, play and work' (p. 1).

It is evident that ANT, with its integration of non-human objects is consistent with the mobilities paradigm and together these concepts of performance, embodiment, mobility, hopeful tourism, actor networks and the non-representational have had strong influences on articles published in the two volumes of Annals under discussion. With regard to embodied experiences, Waitt and Duffy (2010) for 
example speak of the importance of developing 'sonic knowledge' which brings the 'listening body' into tourism studies while Valtonen and Viejola (2011) in their discussion of sleep in tourism contend that we are witnessing 'paradigmatic shifts in tourism from the gaze to the body, from authenticity to performativity and from representations to everyday habits and practices' (p. 176). Frohlick and Johnston (2011) demonstrate how tourism media campaigns 'employ familiar tropes...which discursively construct places and bodies as 'natural', 'exotic' and 'romantic' (p. 1090). Uriely et al's (2011) study of tourist deviant behaviour using psychoanalytic sociology is also consistent with the move to decrease the distance between tourism and everyday life

Baldacchino (2010) also draws on the concepts of performance, embodiment and mobility in his study of a seemingly innocuous substance - sand. He suggests that

'it is the embodied engagement with materiality that constructs personal and social identity and within the Western imaginary, sand on a beach conveys this dialectic co-production by ushering in a whole repertoire of doing or body techniques which socialise and constitute us temporarily as pleasure-cum-tactile seeking subjects....[sand is] a thing in the making which...incorporated through stylized and socio-culturally packaged body work and performance' (p. 775).

Scarles (2010) also speaks of the need to access 'non-representational spaces of encounter and experience' (p. 906). A focus on the mundane and the everyday is also evident in Rickly-Boyd and Metro-Roland's (2010) investigation of touristic experience of place and space in Budapest and Indiana. 
Importantly, while there is now an increasing interest in the non-representational this is not to say that semiotic and discursive analyses do not still have an important role to play in interrogating structures of power and knowledge within tourism. This was evident in some of the articles (d'Hauteserre, 2011; Holman, 2011; Patil, 2011). So that both the representational and the non-representational have a role to play in developing new knowledges about tourism. Perhaps it might be best then to speak of the more-than-representational rather than the non-representational (Haldrup \& Larsen, 2010; Lorimer, 2005).

Finally, our critical reflections turn to the nature of the knowledges produced and here we focus on those knowledges that have relevance for the developing world and mention briefly those knowledges which have been largely occluded from the discussions. We have already pointed to the under-representation of scholars from developing countries in the articles published in the last two volumes, but we feel it is important to determine whether this also means an absence of studies which address the real problems and issues which are faced particularly acutely by developing countries like poverty alleviation, climate change and crime. In terms of the issue of the impacts of climate change in a developing country context, Buzinde et al (2010) in their study of the state of Quintana Roo in Mexico, argue that spatial planning is politically and culturally contested and that if climate change is to be addressed, then society needs to take into account the 'dynamic interactions between an increasingly changing environment... and spatial constructions' (p. 336). Another issue which is of concern for developing countries and which has seen ubiquitous discussion in the tourism literature is the concept of authenticity and cultural commodification. Keir (2010) indicates that we need to understand host populations understandings and contestations of the concept of authenticity which have so far 
been occluded from the tourism literature. In an ethnographic study of a tourist performance in Papua New Guinea he asserts that 'the postmodern critique of object authenticity...has paradoxically often led to the silencing of subaltern political perspectives, for whom authenticity (however constructed or evaluated) can be central to the formulation of a distinct critical political voice' (p. 552).

More inclusive knowledge production is also intimated in Amuquandoh's (2010) investigation of lay concepts of tourism development in a region of Ghana in which he concludes that traditional cultures have an impact on the meanings and interpretations assigned to tourism and so should be taken into account in development strategies. For their part, Krutwaysho and Bramwell (2010) argue for a society-centred' and 'relational' approach to tourism policy implementation using three case studies of tourism related policies in Phuket, Thailand to illustrate their points. Crime is also an issue for tourism in developing societies where there is an obvious gap between the wealth of tourists and that of the local population. Boakye (2010) thus investigates how the "travel preferences of tourists shape the degree to which they become suitable targets for victimization' (p. 731) in the developing country context of Ghana. Cascante (2010) undertakes a micro-level analysis of tourism led development in two Costa Rican villages and advocates the need for 'open communication, widespread participation, tolerance and communion' (p. 1141) amongst tourism stakeholders.

There was only one article which dealt specifically with tourism and poverty alleviation albeit this was not in a developing world context. Deller (2010) undertook a study of rural poverty in the United States with the aim to explore the role of tourism development in changes to the poverty rates in these communities. Deller concluded from his empirical research that, at least as it refers to the population under 
examination, tourism activities did not have any influence on changes in the poverty rate. This brings into question not only claims about tourism's ability to alleviate poverty but also claims that conversely suggest that 'tourism leads to poor jobs and higher poverty rates' (p. 201). The question here is of course whether a similar study conducted in a developing world context would yield the same results.

We have mentioned that postcolonial theory is still a relevant framework of analysis within the context of tourism in terms of both discourse and practice. There were seven articles in both volumes of Annals which adopted a postcolonial perspective Holman (2011); Frohlick and Johnson (2011); Osagie and Buzinde (2011); d'Hautesserre (2011); Patil, (2011); Tucker, (2010) and Lacher and Nepal (2010). The latter in their study of dependency and development in Northern Thailand seek to combine dependency theory with 'postcolonial theory's discursive and representational analysis' (p. 965). They argue that dependency should be examined from a more localised perspective as it can be used to illustrate the relationship between a city and its rural hinterland. This would allow for the development of more micro level strategies for development rather than the traditional way in which tourism and dependency is treated as involving an unequal relationship between the West and the developing world. In this sense then the concepts of power, dependency and control which are central to postcolonial theory can also be manifested within the context of a developing country.

With regard to marginalised voices, it is evident that homosexual voices have been largely silent. This is with one exception - the article by Frohlick and Johnston (2011) examine tourism media campaigns in Costa Rica and New Zealand and reveal the hegemonic conceptualisation of these campaigns in which bodies and spaces are naturalised as heterosexual. Importantly one of the authors self identifies as 
lesbian/queer thus allowing for a more emic perspective to emerge. Another article by Andriotis (2010) and which was previously mentioned draws on the Foucauldian notion of heterotopia to analyse gay friendly nude beaches as erotic oases. He conducts covert participatory observation at a nude gay friendly beach in Crete in order to understand the way in which beach spaces are used to enact transgressive behaviour. However, we do not hear the voices of gay men in this study and so what is presented is a very etic approach. Other notable silences include those from black and ethnic minority groupings within the developed world context who are often marginalised from tourism participation; the extent to which people in the developing world can participate in tourism and the relationship between tourism and peace.

\section{CONCLUSION}

This article has offered some initial observations about the black box of Annals and some of the consequences of its workings for knowledge production. Annals occupies a key position in knowledge production in tourism. It can be viewed as one of a small number of key obligatory passage points (Latour, 1987) which researchers must negotiate in order to add knowledge to the canon. As such it is important to critically reflect on its workings and its outputs, the patterns that emerge, the taken for granted structures, any tendencies to favour or disfavour certain types of knowledge or knowledge agents.

From this initial, exploratory foray a number of issues emerge. On the one hand a rich and dynamic picture is painted of knowledge production and directions. The editorial team represents a broad range of disciplines. Editorial power is not 
centralised through one person or even a small group of editors but widely dissipated amongst expert resource editors. The journal continues to improve its academic impact. On the other hand, despite recent attempts to improve the situation a gender imbalance remains on the editorial team. There are still some geographical areas that are under represented on the editorial team. Journal articles are over represented from some geographical regions and under represented from others. Some voices appear marginalised and silent.

There is more to be done in terms of critical reflexivity and critical action. Future editorials will return to this point and continue to critically examine the extent to which Annals tells "The Truth About Tourism" (Tribe, 2006).

\section{REFERENCES}

Airey, D., \& Chong, K. (2010). National policy-makers for tourism in China. Annals of Tourism Research, 37, 295-314.

Aitchison, C. (2001). Gender and leisure research: The "codification of knowledge". Leisure Sciences, 23, 1-19.

Alcoff, L. (ed) (1998). Epistemology: the big question. Malden MA: Blackwell.

Alegre, J., \& Garau, J. (2010). Tourist satisfaction and dissatisfaction. Annals of Tourism Research, 37, 52-73.

American Heritage ${ }^{\circledR}$ Dictionary of the English Language (2000), Fourth Edition. Houghton Mifflin.

Amoamo, M. (2011). Tourism and hybridity: Revisiting Bhabha's third space. Annals of Tourism Research, 38, 1254-1273.

Amuquandoh, F. (2010). Lay concepts of tourism in Bosomtwe Basin, Ghana. Annals of Tourism Research, 37, 34-51. 
Andriotis, K. (2010). Heterotopic erotic oases: The public nude beach experience. Annals of Tourism Research, 37, 1076-1096.

Andriotis, K. (2011). Genres of heritage authenticity: Denotations from a pilgrimage landscape. Annals of Tourism Research, 38, 1613-1633.

Baggio, R., Scott, N., \& Cooper, C. (2010). Network science: A review focused on tourism. Annals of Tourism Research, 37, 802-827.

Baldacchino, G. (2010). Re-placing materiality: A western anthropology of sand. Annals of Tourism Research, 37, 763-778.

Barros, C., \& Machado, L. (2010). The length of stay in tourism. Annals of Tourism Research, 37, 692-706.

Becken, S. (2011). A critical review of tourism and oil. Annals of Tourism Research, $38,359-379$.

Beritelli, P. (2011). Cooperation among prominent actors in a tourist destination. Annals of Tourism Research, 38, 607-629.

Biran, A., Poria, Y., \& Oren, G. (2011). Sought experiences at (dark) heritage sites. Annals of Tourism Research, 38, 820-841.

Bizjak, B., Knezevic, M., \& Cvetreznik, S. (2011). Attitudes change towards guests with disabilities. Annals of Tourism Research, 38, 842-857.

Boakye, K. (2010). Studying tourists' suitability as crime targets. Annals of Tourism Research, 37, 727-743.

Bosworth, G., \& Farrell, H. (2011). Tourism entrepreneurs in Northumberland. Annals of Tourism Research, 38, 1474-1494.

Buchmann, A., Moore, K., \& Fisher, D. (2010). Experiencing film tourism: Authenticity and fellowship. Annals of Tourism Research, 37, 229-248.

Buckley, R. (2010). Communications in adventure tour products: Health and safety in rafting and kayaking. Annals of Tourism Research, 37, 315-332. 
Buzinde, C., Manuel-Navarrete, D., Kerstetter, D., \& Redclift, M. (2010).

Representation and adaptation to climate change. Annals of Tourism Research, 37, $581-603$.

Buzinde, C., Manuel-Navarrete, D., Yoo, E., \& Morais, D. (2010). Tourists' perceptions in a climate of change: Eroding destinations. Annals of Tourism Research, 37, 333-354.

Caruana, R., \& Crane, A. (2011). Getting away from it all: Exploring freedom in tourism. Annals of Tourism Research, 38, 1495-1515.

Causevic, S., \& Lynch, P. (2011). Phoenix tourism: Post-conflict tourism role. Annals of Tourism Research, 38, 780-800.

Chang, R., Kivela, J., \& Mak, A. (2010). Food preferences of Chinese tourists. Annals of Tourism Research, 37, 989-1011.

Charmaz, K. and Mitchell, R.G. (1997). The myth of silent authorship: Self, substance and style in ethnographic writing. In Hertz, R. (ed.), Reflexivity and voice(pp.193-215). London: Sage.

Cohen, E. H. (2011). Educational dark tourism at an in populo site. Annals of Tourism Research, 38, 193-209.

Cohen, S. (2011). Lifestyle travelers: Backpacking as a way of life. Annals of Tourism Research, 38, 1535-1555.

Cohen, S., Higham, J., \& Cavaliere, C. (2011). Binge flying: Behavioral addiction and climate change. Annals of Tourism Research, 38, 1070-1089.

Collins-Kreiner, N. (2010). Researching pilgrimage: Continuity and transformations. Annals of Tourism Research, 37, 440-456.

Conran, M. (2011). They really love me: Intimacy in volunteer tourism. Annals of Tourism Research, 38, 1454-1473.

Cooper, C. (2006). Knowledge management and tourism. Annals of Tourism Research, 
$33,47-64$

d'Hauteserre, A. (2011). Politics of imaging New Caledonia. Annals of Tourism Research, 38, 380-402.

Decrop, A. (2010). Destination choice sets: An inductive longitudinal approach. Annals of Tourism Research, 37, 93-115.

Deller, S. (2010). Rural poverty, tourism and spatial heterogeneity. Annals of Tourism Research, 37, 180-205.

Denstadli, J., Jacobsen, J., \& Lohmann, M. (2011). Tourist perceptions of summer weather in Scandinavia. Annals of Tourism Research, 38, 920-940.

Dominguez-Mujica, J., Gonzalez-Perez, J., \& Parreno-Castellano, J. (2011). Tourism and human mobility in Spanish archipelagos. Annals of Tourism Research, 38, $586-606$.

Enoch, Y., \& Grossman, R. (2010). Blogs of Israeli and Danish backpackers to India. Annals of Tourism Research, 37, 520-536.

Eriksson, S. (2010). A rarity show of modernity: Sweden since the 1920s. Annals of Tourism Research, 37, 74-92.

Erkus-Ozturk, H., \& Eraydin, A. (2011). Factors of global connectivity in Antalya's tourism. Annals of Tourism Research, 38, 1300-1321.

Farsari, I., Butler, R., \& Szivas, E. (2011). Complexity in tourism policies: A cognitive mapping approach. Annals of Tourism Research, 38, 1110-1134.

Feighery, W. (2011). Consulting ethics. Annals of Tourism Research, 38, 1031-1050.

Frantal, B., \& Kunc, J. (2011). Wind turbines in tourism landscapes: Czech experience. Annals of Tourism Research, 38, 499-519.

Frechtling, D. (2010). The tourism satellite account: A primer. Annals of Tourism Research, 37, 136-153.

Frohlick, S., \& Johnston, L. (2011). Naturalizing bodies and places: Tourism media 
campaigns and heterosexualities in Costa Rica and New Zealand. Annals of Tourism Research, 38, 1090-1109.

Frost, W. (2010). Life changing experiences: Film and tourists in the Australian outback. Annals of Tourism Research, 37, 707-726.

Garay, L., \& Canoves, G. (2011). Life cycles, stages and tourism history: The Catalonia (Spain) experience. Annals of Tourism Research, 38, 651-671.

Gelbman, A., \& Timothy, D. (2011). Border complexity, tourism and international exclaves: A case study. Annals of Tourism Research, 38, 110-131.

Goulding, C., \& Shankar, A. (2011). Club culture, neotribalism and ritualized behaviour. Annals of Tourism Research, 38, 1435-1453.

Gretzel, U. (2011). Intelligent systems in tourism: A social scientific perspective. Annals of Tourism Research, 38, 757-779.

Gurel, E., Altinay, L., \& Daniele, R. (2010). Tourism students’ entrepreneurial intentions. Annals of Tourism Research, 37, 646-669.

Haldrup, M., \& Larsen, J. (2010). Tourism, performance and the everyday. London: Routledge.

Haugland, S., Ness, H., Gronseth, B., \& Aarstad, J. (2011). Development of tourism destinations: An integrated multilevel perspective. Annals of Tourism Research, 38, $268-290$.

Henwood, K., \& Pidgeon, N. (1993). Qualitative research and psychological theorising. In Hammersely, M. (ed.), Social Research: Philosophy, politics and practice (pp.14-32). London: Sage.

Hertz, R. (ed). (1997). Reflexivity and voice. London: Sage.

Holman, C. (2011). Surfing for a shaman: Analyzing an Ayahuasca website. Annals of Tourism Research, 38, 90-109.

Hung, K., \& Petrick, J. (2010). Developing a measurement scale for constraints to 
cruising. Annals of Tourism Research, 37, 206-228.

Hyde, K., \& Olesen, K. (2011). Packing for touristic performances. Annals of Tourism Research, 38, 900-919.

Jamal, T., \& Hollinshead, K. (2001). Tourism and the forbidden zone: The underserved power of qualitative inquiry. Tourism Management, 22,63-82.

Janta, H., Brown, L., Lugosi, P., \& Ladkin, A. (2011). Migrant relationships and tourism employment. Annals of Tourism Research, 38, 1322-1343.

Kasak, S., Kline, C., \& Lamoureux, K. (2011). Modeling tourist and community decision making : The SAVE market. Annals of Tourism Research, 38, 1387-1409.

Knight, J. (2010). The ready-to-view wild monkey: The convenience principle in Japanese wildlife tourism. Annals of Tourism Research, 37, 744-762.

Krider, R., Arguello, A., Campbell, C., \& Mora, J. (2010). Trait and image interaction in ecotourism preference. Annals of Tourism Research, 37, 779-801.

Krutwaysho, O., \& Bramwell, B. (2010). Tourism policy implementation and society. Annals of Tourism Research, 37, 670-691.

Lacher, G., \& Nepal, S. (2010). Dependency and development in northern Thailand. Annals of Tourism Research, 37, 947-968.

Ladkin, A. (2011). Exploring tourism labor. Annals of Tourism Research, 38, 1135-1155.

Laing, J., \& Crouch, G. (2011). Frontier tourism: Retracing mythic journeys. Annals of Tourism Research, 38, 1516-1534.

Larsen, S., Ogaard, T., \& Brun, W. (2011). Backpackers and mainstreamers: Realities and myths. Annals of Tourism Research, 38, 690-707.

Latour, B. (1987). Science in action: How to follow scientists and engineers around society. Cambridge, MA: Harvard University Press.

Latour, B. (1999). Pandora's hope: Essays on the reality of science studies. 
Cambridge, MA: Harvard University Press.

Lau, R. (2010). Revisiting authenticity: A social realist approach. Annals of Tourism Research, 37, 478-498.

Lee, T., Riley, M., \& Hampton, M. (2010). Conflict and progress: Tourism development in Korea. Annals of Tourism Research, 37, 355-376.

Lorenzini, E., Calzati, V., \& Giudici, P. (2011). Territorial brands for tourism development : A statistical analysis on the Marche region. Annals of Tourism Research, 38, 540-560.

Lorimer, H. (2005). Cultural geography: The busyness of being more-than-representational. Progress in Human Geography, 29(3), 83-94.

Mansson, M. (2011). Mediatized tourism. Annals of Tourism Research, 38, 1634-1652.

Maoz, D., \& Bekerman, Z. (2010). Searching for Jewish answers in Indian resorts. The postmodern traveler. Annals of Tourism Research, 37, 423-439.

Martin, K. (2010). Living pasts: Contested tourism authenticities. Annals of Tourism Research, 37, 537-554.

Matarrita-Cascante, D. (2010). Beyond growth: Reaching tourism-led development. Annals of Tourism Research, 37, 1141-1163.

McCabe, S., \& Stokoe, E. (2010). Have you been away? Holiday talk in everyday interaction. Annals of Tourism Research, 37, 1117-1140.

Miller, G., Rathouse, K., Scarles, C., Holmes, K., \& Tribe, J. (2010). Public understanding of sustainable tourism. Annals of Tourism Research, 37, 627-645.

Mowatt, R., \& Chancellor, C. (2011). Visiting death and life: Dark tourism and slave castles. Annals of Tourism Research, 38, 1410-1434.

Murphy, E., Dingwall, R., Greatbach, D., Parker, S., Watson, P. (1998). Qualitative research methods in health technology assessment: A review of the literature. 
Health Technology Assessment 2 (16), 1-274.

Nam, J., Ekinci, Y., \& Whyatt, G. (2011). Brand equity, brand loyalty and consumer satisfaction. Annals of Tourism Research, 38, 1009-1030.

Nicolau, J. (2011). Monetary and non-monetary efforts for leisure activities. Annals of Tourism Research, 38, 801-819.

Nunkoo, R., \& Ramkissoon, H. (2011). Developing a community support model for tourism. Annals of Tourism Research, 38, 964-988.

Nyaupane, G., \& Poudel, S. (2011). Linkages among biodiversity, livelihood, and tourism. Annals of Tourism Research, 38, 1344-1366.

Nyaupane, G., \& Timothy, D. (2010). Power, regionalism, and tourism policy in Bhutan. Annals of Tourism Research, 37, 969-988.

Osagie, I., \& Buzinde, C. (2011). Culture and postcolonial resistance: Antigua in Kincaid's A Small Place. Annals of Tourism Research, 38, 210-230.

Paget, E., Dimanche, F., \& Mounet, J. (2010). A tourism innovation case: An actor-network approach. Annals of Tourism Research, 37, 828-847.

Pan, B., \& Fesenmaier, D. (2006). Online information search: Vacation planning process. Annals of Tourism Research, 33, 809-832.

Pan, B., \& Li, X. (2011). The long tail of destination image and online marketing. Annals of Tourism Research, 38, 132-152.

Papathanassis, A., \& Beckmann, I. (2011). Assessing the 'poverty of cruise theory' hypothesis. Annals of Tourism Research, 38, 153-74.

Park, H. (2010). Heritage tourism: Emotional journeys into nationhood. Annals of Tourism Research, 37, 116-135.

Park, H. (2011). Shared national memory as intangible heritage: Re-imagining two Koreas as one nation. Annals of Tourism Research, 38, 520-539.

Patil, V. (2011). Narrating political history about contested space: Tourism websites of 
India's Northeast. Annals of Tourism Research, 38, 989-1008.

Pernecky, T., \& Jamal, T. (2010). (Hermeneutic) Phenomenology of tourism studies. Annals of Tourism Research, 37, 1055-1075.

Pine, J., \& Gilmore, J. (2007). Authenticity: What consumers really want? Harvard: Harvard Business School Press.

Povilanskas, R., \& Armaitiene, A. (2011). Seaside resort-hinterland nexus: Palanga, Lithuania. Annals of Tourism Research, 38, 1156-1177.

Pratt, S. (2011). Economic linkages and impacts across the TALC. Annals of Tourism Research, 38, 630-650.

Pritchard, A., Morgan, N., \& Ateljevic, I. (2011). Hopeful tourism: A new transformative perspective. Annals of Tourism Research, 38, 941-963.

Racheria, P., \& Hu, C. (2010). A social network perspective of tourism research collaborations. Annals of Tourism Research, 37, 1012-1034.

Rantala, O. (2010). Tourist practices in the forest. Annals of Tourism Research, 37, 249-264.

Reijnders, S. (2011). Stalking the count: Dracula, fandom, and tourism. Annals of Tourism Research, 38, 231-248.

Reisinger, Y., \& Steiner, C. (2006). Reconceptualizing object authenticity. Annals of Tourism Research, 33, 65-86.

Ren, C. (2011). Non-human agency, radical ontology and tourism realities. Annals of Tourism Research, 38, 858-881.

Ren, C., Pritchard, A., \& Morgan, N. (2010). Constructing tourism research: a critical inquiry. Annals of Tourism Research, 37, 885-904.

Richards, G. (2011). Creativity and tourism: The state of the art. Annals of Tourism Research, 38, 1225-1253.

Richards, V., Pritchard, A., \& Morgan, N. (2010). (Re)envisioning tourism and visual 
impairment. Annals of Tourism Research, 37, 1097-1116.

Rickly-Boyd, J., \& Metro-Roland, M. (2010). Background to the fore: The prosaic in tourist places. Annals of Tourism Research, 37, 1164-1180.

Rittichainuwat, B. (2011). Ghosts: A travel barrier to tourism recovery. Annals of Tourism Research, 38, 437-459.

Saarinen, J. (2006). Traditions of sustainability in tourism studies. Annals of Tourism Research, 33, 1121-1140.

Scarles, C. (2010). Where words fail, visuals ignite: Opportunities for visual autoethnography in tourism research. Annals of Tourism Research, 37, 905-926.

Schwandt, T. (1994). Constructivist, interpretivist approaches to human inquiry. In Denzin, N., \& Lincoln, Y. (eds). Handbook of qualitative research (pp.118-137). London: Sage.

Sedgley, D., Pritchard, A., \& Morgan, N. (2011). Tourism and ageing: A transformative agenda. Annals of Tourism Research, 38, 422-436.

Seetanah, B. (2011). Assessing the dynamic economic impact of tourism for island economies. Annals of Tourism Research, 38, 291-308.

Seglen, P. (1997). Citations and journal impact factors: questionable indicators of research quality. Allergy, 52, 1050-1056.

Sharpley, R., \& Jepson, D. (2011). Rural tourism: A spiritual experience? Annals of Tourism Research, 38, 52-71.

Sheller, M., \& Urry, J. (eds.) (2004). Tourism mobilities: Places to play, places in play. London: Routledge.

Shen, S., Li, G., \& Song, H. (2011). Combination forecasts of international tourism demand. Annals of Tourism Research, 38, 72-89.

Shoval, N., McKercher, B., Ng, E., \& Birenboim, A. (2011). Hotel location and tourist activity in cities. Annals of Tourism Research, 38, 1594-1612. 
Silverman, D. (1993). Interpreting qualitative data: Methods for analysing talk, text and interaction. London: Sage.

Smallman, C., \& Moore, K. (2010). Process studies of tourists' decision-making. Annals of Tourism Research, 37, 397-422.

Song, H., Kim, J., \& Yang, S. (2010). Confidence intervals for tourism demand elasticity. Annals of Tourism Research, 37, 377-396.

Strickland-Munro, J., Allison, H., \& Moore, S. (2010). Using resilience concepts to investigate the impacts of protected area tourism on communities. Annals of Tourism Research, 37, 499-519.

Stylianou-Lambert, T. (2011). Gazing from home: Cultural tourism and art museums. Annals of Tourism Research, 38, 403-421.

Tribe, J. (2006). The truth about tourism. Annals of Tourism Research, 33, 360-381.

Tribe, J. (2008). Tourism a critical business. Journal of Travel Research, 46, 245-255.

Tribe, J. (2010). Tribes, territories and networks in the tourism academy. Annals of Tourism Research, 37, 7-33.

Tribe, J., \& Xiao, H. (2011). Developments in tourism social science. Annals of Tourism Research, 38, 7-26

Tsaur, S., Yen, C., \& Chen, C. (2010). Independent tourist knowledge and skills. Annals of Tourism Research, 37, 1035-1054.

Tucker, H. (2010). Peasant-entrepreneurs: A longitudinal ethnography. Annals of Tourism Research, 37, 927-946.

Tung, V., \& Ritchie, J. R. B. (2011). Exploring the essence of memorable tourism experiences. Annals of Tourism Research, 38, 1367-1386.

Uriely, N., Ram, Y., \& Malach-Pines, A. (2011). Psychoanalytic sociology of deviant tourist behavior. Annals of Tourism Research, 38, 1051-1069.

Urry, J. (1990). The tourist gaze. London: Sage. 
Valtonen, A., \& Veijola, S. (2011). Sleep in tourism. Annals of Tourism Research, 38, 175-192.

Vargas-Sanchez, A., Porras-Bueno, N., \& Plaza-Mejia, M. (2011). Explaining residents' attitudes to tourism: Is a universal model possible? Annals of Tourism Research, 38, 460-480.

Waitt, G., \& Duffy, M. (2010). Listening and tourism studies. Annals of Tourism Research, 37, 457-477.

Wang, K., Jao, P., Chan, H., \& Chung, C. (2010). Group package tour leaders' intrinsic risks. Annals of Tourism Research, 37, 154-179.

Ward, C., \& Berno, T. (2011). Beyond social exchange theory: Attitudes towards tourists. Annals of Tourism Research, 38, 1556-1569.

Watkins, L., \& Gnoth, J. (2011). The value orientation approach to understanding culture. Annals of Tourism Research, 38, 1274-1299.

Weaver, A. (2011). Tourism and the military: Pleasure and the war economy. Annals of Tourism Research, 38, 672-689.

Weaver, D. (2011). Contemporary tourism heritage as heritage tourism: Evidence from Las Vegas and Gold Coast. Annals of Tourism Research, 38, 249-267.

Weidenfeld, A., Williams, A., \& Butler, R. (2010). Knowledge transfer and innovation among attractions. Annals of Tourism Research, 37, 604-626.

Williams, A., \& Shaw, G. (2011). Internationalization and innovation in tourism. Annals of Tourism Research, 38, 27-51.

Wong, C., \& McKercher, B. (2011). Tourist information center staff as knowledge brokers: The case of Macau. Annals of Tourism Research, 38, 481-498.

Wong, E., Mistilis, N., \& Dwyer, L. (2011). A model of Asian collaboration in tourism. Annals of Tourism Research, 38, 882-899.

Yang, L. (2011). Ethnic tourism and cultural representation. Annals of Tourism 
Research, 38, 561-585.

Zhao, W., Ritchie, J. R. B., \& Echtner, C. (2011). Social capital and tourism entrepreneurship. Annals of Tourism Research, 38, 1570-1593. 